\title{
A New Insight in the Physical and Photoelectrochemical Properties of Molybdenum Disulfide Alpha-Hematite Nanocomposite Films
}

\author{
Hussein Alrobei ${ }^{1}$, Ashok Kumar' ${ }^{1}$ Manoj K. Ram ${ }^{2}$ \\ ${ }^{1}$ Department of Mechanical Engineering, University of South Florida, Tampa, FL, USA \\ ${ }^{2}$ Clean Energy Research Center, University of South Florida, Tampa, FL, USA \\ Email:mkram@usf.edu; manojkram@gmail.com
}

How to cite this paper: Alrobei, $\mathrm{H}$., $\mathrm{Ku}-$ mar, A. and Ram, M.K. (2017) A New Insight in the Physical and Photoelectrochemical Properties of Molybdenum Disulfide Alpha-Hematite Nanocomposite Films. American Journal of Analytical Chemistry, 8, 523-539.

https://doi.org/10.4236/ajac.2017.88038

Received: July 20, 2017

Accepted: August 28, 2017

Published: August 31, 2017

Copyright $\odot 2017$ by authors and Scientific Research Publishing Inc. This work is licensed under the Creative Commons Attribution International License (CC BY 4.0).

http://creativecommons.org/licenses/by/4.0/

\begin{abstract}
The alpha $(\alpha)$-hematite $\left(\mathrm{Fe}_{2} \mathrm{O}_{3}\right)$ as photoanode has been used for photoelectrochemical applications due to low bandgap, low cost, high chemical stability, nontoxicity, and abundance in nature. The doping with various transition metals, formation of nanostructured and nanocomposite of $\alpha-\mathrm{Fe}_{2} \mathrm{O}_{3}$ have been attempted to enrich the carrier mobility, surface kinetics and carrier diffusion properties. The manuscript is an attempt to improve the photoelectrochemical properties of $\alpha-\mathrm{Fe}_{2} \mathrm{O}_{3}$ by formation of nanocomposite with dichalcogenide (molybdenum disulfide $\left(\mathrm{MoS}_{2}\right)$ nanomaterials. The nanocomposite of $\mathrm{MoS}_{2}$ $\alpha-\mathrm{Fe}_{2} \mathrm{O}_{3}$ have been synthesized by varying the amount of $\mathrm{MoS}_{2}$ in sol-gel synthesis process. The nanocomposite $\mathrm{MoS}_{2}-\alpha-\mathrm{Fe}_{2} \mathrm{O}_{3}$ materials were characterized using UV-visible, FTIR, SEM, X-ray diffraction, Raman and particle analyzer. The photoelectrochemical properties were investigated using cyclic voltammetry and chronoamperometry studies. The optical and structural properties of $\mathrm{MoS}_{2}-\alpha-\mathrm{Fe}_{2} \mathrm{O}_{3}$ nanocomposite have been found to be dependent on $\mathrm{MoS}_{2}$ doping. The band gap has shifted whereas; the structure is more prominent as flower-like morphology, which is a result of doping of $\mathrm{MoS}_{2}$. The photocurrent is more pronounced with and without light exposition to $\mathrm{MoS}_{2}-\alpha-\mathrm{Fe}_{2} \mathrm{O}_{3}$ based electrode in photoelectrochemical cell. We have understood the photoelectrochemical water splitting using nanocomposite $\alpha-\mathrm{Fe}_{2} \mathrm{O}_{3}$ $\mathrm{MoS}_{2}$ through schematic representation based on experimental results. The enhanced photoelectrochemical properties of nanocomposite $\alpha-\mathrm{Fe}_{2} \mathrm{O}_{3}-\mathrm{MoS}_{2}$ films have been observed as compared to pristine $\alpha-\mathrm{Fe}_{2} \mathrm{O}_{3}$ and transition metal doped $\alpha-\mathrm{Fe}_{2} \mathrm{O}_{3}$ nanostructured films.
\end{abstract}




\section{Keywords}

Water Splitting, Photoelectrochemical, Hematite $\left(\alpha-\mathrm{Fe}_{2} \mathrm{O}_{3}\right), \mathrm{MoS}_{2}$, Nanocomposite

\section{Introduction}

Photoelectrochemical cell (PEC) produces hydrogen through splitting the water using renewable sources (i.e., the sun) [1] [2] [3]. Photoelectrochemical (PEC) cells have been used to convert solar energy to hydrogen gas by splitting water into hydrogen and oxygen, hence offering clean and renewable energy [4]. Moreover, photoelectrochemical (PEC) has attracted attention since Honda and Fujishima utilized the first application of titanium dioxide $\left(\mathrm{TiO}_{2}\right)$ in 1972 [5]. Nevertheless, the large bandgap of $\mathrm{TiO}_{2}(3.1-3.3 \mathrm{eV})$ impedes the absorption of visible light, and limits the solar-to-hydrogen efficiency to $2.2 \%$ [5]. So, it is necessary to use material that has small bandgap and easy to harvest energy from sunlight (visible light 53\%) [6]. Iron oxide, bismuth vanadate, tungsten oxide, and tantalum nitride are the examples of low band gap semiconducting materials [5]. The $\alpha-\mathrm{Fe}_{2} \mathrm{O}_{3}$ is one of the most attractive photo-anode materials with efficiency of $16 \%$ to convert solar-to-hydrogen [5] [7]-[14]. The $\alpha-\mathrm{Fe}_{2} \mathrm{O}_{3}$ has been applied for photoelectrochemical applications due to low bandgap $(2.1-2.2 \mathrm{eV})$, low cost, high chemical stability, nontoxicity, and abundance in nature [5]. However, $\alpha-\mathrm{Fe}_{2} \mathrm{O}_{3}$ also has several drawbacks such as shorter hole diffusion length, low conductivity, shorter life time of photoexcitation and deprived reaction kinetics of oxygen evolution in photoelectrochemical applications [15]. The doping with several metallic ions such as zinc [16], titanium [17] [18], molybdenum [19], aluminum [20], platinum [21], silicon [22] [23] [24], graphene [25] [26], and cadmium sulfide [27] have shown improved PEC performance. The zinc and aluminum doped $\alpha-\mathrm{Fe}_{2} \mathrm{O}_{3}$ have shown enhanced photoelectrochemical properties compared to $\alpha$ - $\mathrm{Fe}_{2} \mathrm{O}_{3}$ nanostructures [28] [29] [30].

Recently, two-dimensional (2D) dichalcogenide material "molybdenum disulfide $\left(\mathrm{MoS}_{2}\right)$ " with bandgap of $1.8 \mathrm{eV}$ has been used as $\mathrm{n}$-and p-types structures for photoelectrochemical studies [5]. The $\mathrm{MoS}_{2}$ shows stimulating photocatalytic activity due to its bonding, chemical composition, doping, and nanoparticles growth on various film matrices, and has been used for hydrogen production in nanocluster structures [2] [31] [32] [33] [34]. Besides, $\mathrm{MoS}_{2}$ has shown different applications in photocatalyst, phototransistors and sensors applications [5]. It is understood that $\mathrm{MoS}_{2}$ could help to play an important role as the charge transfer with slow recombination of electron-hole pairs created due to photoenergy with the charge transfer rate between surface and electrons [35].

Under this work, $\mathrm{MoS}_{2}$ particles were used to promote electron transport properties of the $\alpha-\mathrm{Fe}_{2} \mathrm{O}_{3}$ nanomaterial by doping and homogenous structure due to $\mathrm{MoS}_{2}-\alpha-\mathrm{Fe}_{2} \mathrm{O}_{3}$ nanomaterials. The doping of $\mathrm{MoS}_{2}$ particles varied by 
$0.1 \%, 0.2 \%, 0.5 \%, 1 \%, 2 \%$ and $5 \%$ in $\alpha-\mathrm{Fe}_{2} \mathrm{O}_{3}$. The $\mathrm{MoS}_{2}-\alpha-\mathrm{Fe}_{2} \mathrm{O}_{3}$ nanomaterials were characterized using X-ray diffraction, SEM, FTIR, Raman spectroscopy, particle analyzer, and UV-vis techniques. The cyclic voltammetry (CV) and impedance measurements were utilized to understand the electrochemical electrode/electrolyte interface and photoelectrochemical properties of $\mathrm{MoS}_{2}-\alpha-\mathrm{Fe}_{2} \mathrm{O}_{3}$ based nanostructures for water splitting applications.

\section{Experimental Details}

\subsection{Materials}

The materials iron chloride $\left(\mathrm{FeCl}_{3}\right)$, aluminum chloride $\left(\mathrm{AlCl}_{3}\right)$, sodium hydroxide $(\mathrm{NaOH}), \mathrm{MoS}_{2}$, and ammonium hydroxide $\left(\mathrm{NH}_{4} \mathrm{OH}\right)$ were purchased from Sigma-Aldrich. The fluorine tin oxide (FTO) coated glass with resistance of $\sim 10 \Omega$ was also procured from Sigma-Aldrich. The centrifuged containers were purchased to clean the synthesized nanomaterials from the solution.

\subsection{Experimental Procedure}

$\alpha-\mathrm{Fe}_{2} \mathrm{O}_{3}$ and $\mathrm{MoS}_{2}-\alpha-\mathrm{Fe}_{2} \mathrm{O}_{3}$ were synthesized by a sol-gel technique as shown in Equation (1).

$$
\mathrm{FeCl}_{3} \cdot 6 \mathrm{H}_{2} \mathrm{O}+\mathrm{MoS}_{2} \underset{\mathrm{NaOH}\left(\text { heat } 110^{\circ} \mathrm{C}\right) / \text { sonination } / \text { dry } / \text { heat }}{\longrightarrow} \mathrm{MoS}_{2}-\mathrm{Fe}_{2} \mathrm{O}_{3}
$$

Table 1 shows the amount of chemicals used for the synthesis of $\mathrm{MoS}_{2}-\alpha-\mathrm{Fe}_{2} \mathrm{O}_{3}$. Different concentrations of $\mathrm{FeCl}_{3}$ with $\mathrm{MoS}_{2}$ were prepared in $500 \mathrm{ml}$ round bottom flasks. $\mathrm{NaOH}$ solution was added to the resulting solution and stirred with a magnet for an hour. A condenser was connected to the round bottom flask, which allowed chemical reaction to proceed at $90^{\circ} \mathrm{C}-100^{\circ} \mathrm{C}$. The reaction was terminated after 24 hours, and the solution was cooled at room temperature. The synthesized material was separated using a centrifuge and continuous cleaning with water and initially left drying in room temperature. The synthesized materials containing different ratios of $\alpha-\mathrm{Fe}_{2} \mathrm{O}_{3}$ to $\mathrm{MoS}_{2}$ in $\mathrm{MoS}_{2}-\alpha-\mathrm{Fe}_{2} \mathrm{O}_{3}$ were obtained. Figure 1 shows the photographs of the $\mathrm{MoS}_{2}-\alpha-\mathrm{Fe}_{2} \mathrm{O}_{3}$ materials synthesized using various percentage of $\mathrm{MoS}_{2}$ to $\alpha-\mathrm{Fe}_{2} \mathrm{O}_{3}$. The immediate doping of $0.1 \% \mathrm{MoS}_{2}$ changes the color of $\alpha-\mathrm{Fe}_{2} \mathrm{O}_{3}$, whereas the dark red color can be visualized with the increase of $\mathrm{MoS}_{2}$ percentage in $\alpha-\mathrm{Fe}_{2} \mathrm{O}_{3}$. The $\mathrm{MoS}_{2}-\alpha-\mathrm{Fe}_{2} \mathrm{O}_{3}$ at various ratio were dried at various temperatures $\left(100^{\circ} \mathrm{C}, 200^{\circ} \mathrm{C}, 300^{\circ} \mathrm{C}, 400^{\circ} \mathrm{C}\right.$,

Table 1. The amount of chemical used for synthesis of $\mathrm{MoS}_{2}$-composite $\alpha$-hematite.

\begin{tabular}{ccccccc}
\hline Chemicals & $\begin{array}{c}0.1 \% \mathrm{MoS}_{2} \\
\text { w.r. to } \mathrm{FeCl}_{3}\end{array}$ & $\begin{array}{c}0.2 \% \mathrm{MoS}_{2} \\
\text { w.r. to } \mathrm{FeCl}_{3}\end{array}$ & $\begin{array}{c}0.5 \% \mathrm{MoS}_{2} \\
\text { w.r. to } \mathrm{FeCl}_{3}\end{array}$ & $\begin{array}{c}1 \% \mathrm{MoS}_{2} \\
\text { w.r. to } \mathrm{FeCl}_{3}\end{array}$ & $\begin{array}{c}2 \% \mathrm{MoS}_{2} \\
\text { w.r. to } \mathrm{FeCl}_{3}\end{array}$ & $\begin{array}{c}5 \% \mathrm{MoS}_{2} \\
\text { w.r. to } \mathrm{FeCl}_{3}\end{array}$ \\
\hline $\mathrm{FeCl}_{3}$ & $6.8 \mathrm{~g}$ & $6.8 \mathrm{~g}$ & $6.8 \mathrm{~g}$ & $6.8 \mathrm{~g}$ & $6.8 \mathrm{~g}$ & $6.8 \mathrm{~g}$ \\
$\mathrm{MoS}_{2}$ & $0.013 \mathrm{~g}$ & $0.026 \mathrm{~g}$ & $0.065 \mathrm{~g}$ & $0.1296 \mathrm{~g}$ & $0.2592 \mathrm{~g}$ & $0.648 \mathrm{~g}$ \\
$\mathrm{NaOH}$ & $4.8 \mathrm{~g}$ & $4.8 \mathrm{~g}$ & $4.8 \mathrm{~g}$ & $4.8 \mathrm{~g}$ & $4.8 \mathrm{~g}$ & $4.8 \mathrm{~g}$ \\
$\mathrm{C}_{19} \mathrm{H}_{42} \mathrm{BrN}$ & $0.5 \mathrm{~g}$ & $0.5 \mathrm{~g}$ & $0.5 \mathrm{~g}$ & $0.5 \mathrm{~g}$ & $0.5 \mathrm{~g}$ & $0.5 \mathrm{~g}$ \\
\hline
\end{tabular}




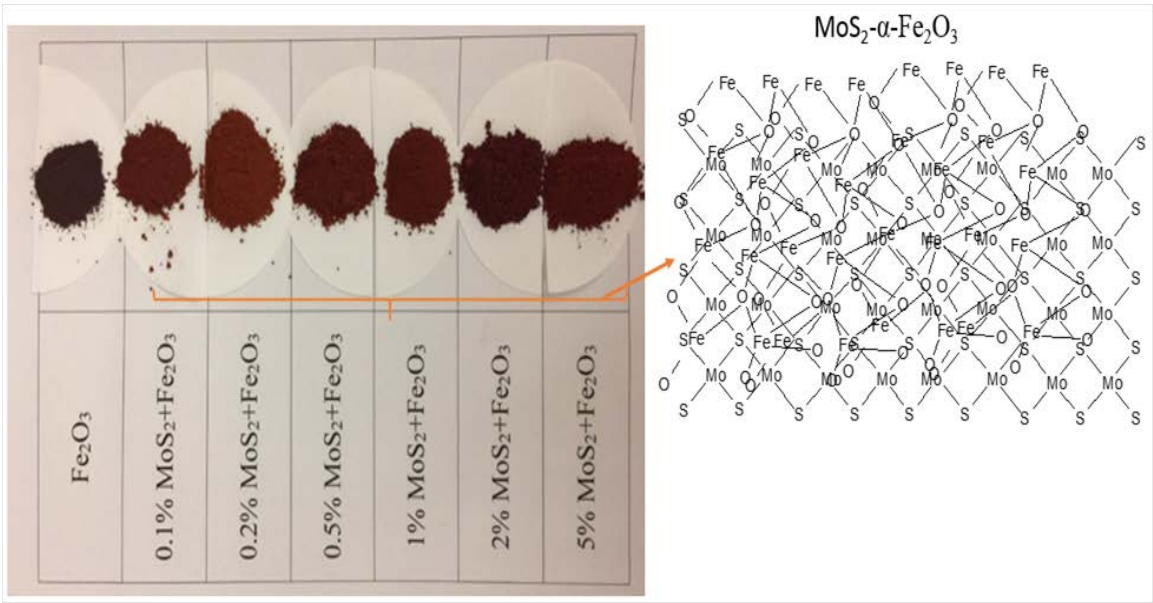

Figure 1. The synthesized $\alpha$-hematite $\left(\alpha-\mathrm{Fe}_{2} \mathrm{O}_{3}\right)$ and $\mathrm{MoS}_{2}-\alpha$ - $\mathrm{Fe}_{2} \mathrm{O}_{3}$ composite materials.

and $500^{\circ} \mathrm{C}$ ). In each case, the temperature was maintained in furnace for one hour. The materials were collected by cooling at room temperature and stored in a tight bottle for characterization as well preparation of electrodes for electrochemical and photochemical studies.

\subsection{The Film Formation of Substrate}

The $\mathrm{MoS}_{2}-\alpha-\mathrm{Fe}_{2} \mathrm{O}_{3}$ was prepared at different concentrations by mixing with acetic acid to obtain the homogenous solution to cast film on various substrates. $500 \mathrm{mg}$ of $\mathrm{MoS}_{2}-\alpha-\mathrm{Fe}_{2} \mathrm{O}_{3}(0.1 \%, 0.2 \%, 0.5 \%, 1 \%, 2 \%$, and $5 \%)$ was grinded and then mixed into $10 \mathrm{ml}$ acetic acid in a container, and left for 10 hours. Later, homogenous colloidal solution containing $\mathrm{MoS}_{2}-\alpha-\mathrm{Fe}_{2} \mathrm{O}_{3}$ with acetic acid were used to make films on quartz, silicon, and fluorine tin oxide (FTO) coated glass plates. The films were cured at different temperatures $\left(100^{\circ} \mathrm{C}, 200^{\circ} \mathrm{C}, 300^{\circ} \mathrm{C}\right.$, $400^{\circ} \mathrm{C}$, and $500^{\circ} \mathrm{C}$ ) for an hour. It has been observed that the nanomaterials treated at $100^{\circ} \mathrm{C}$ to $200^{\circ} \mathrm{C}$ could still have the water molecules. However, the temperature at around $300^{\circ} \mathrm{C}$ allowed to have a solid material. The nanomaterials were further treated to $400^{\circ} \mathrm{C}$ and $500^{\circ} \mathrm{C}$. The XRD, SEM, cyclic voltammetry, and UV-vis characterizations were performed in room temperature in cooled samples which were heated till $500^{\circ} \mathrm{C}$ of $\mathrm{MoS}_{2}-\alpha-\mathrm{Fe}_{2} \mathrm{O}_{3}$ films. We had observed passivation, change in structure and morphology in the samples treated at $300^{\circ} \mathrm{C}, 400^{\circ} \mathrm{C}$ and $500^{\circ} \mathrm{C}$. However, the results are presented for the samples treated at $500^{\circ} \mathrm{C}$ due to their enhance photocurrent.

\section{Results and Discussions}

\subsection{UV-Vis Studies}

Figure 2 shows the UV-vis spectra of $\alpha-\mathrm{Fe}_{2} \mathrm{O}_{3}, \mathrm{MoS}_{2}$ and $\alpha-\mathrm{Fe}_{2} \mathrm{O}_{3}-\mathrm{MoS}_{2}$-prepared at a different ratio of $\mathrm{MoS}_{2}$ to $\alpha-\mathrm{Fe}_{2} \mathrm{O}_{3}$. An UV-Vis Spectrometer Jasco V-530 was used to measure the absorption spectra on various samples deposited on glass plates. Figure 2(a) shows the UV-vis absorption at around $550 \mathrm{~nm}$ for the 


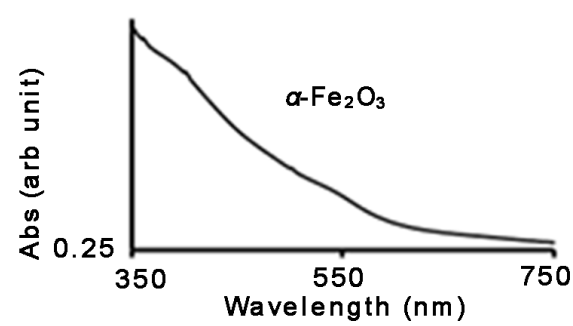

(a)

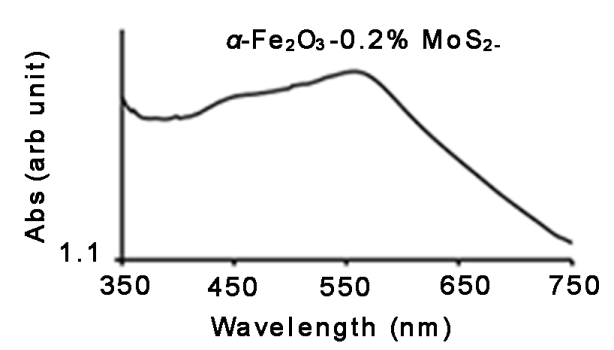

(d)

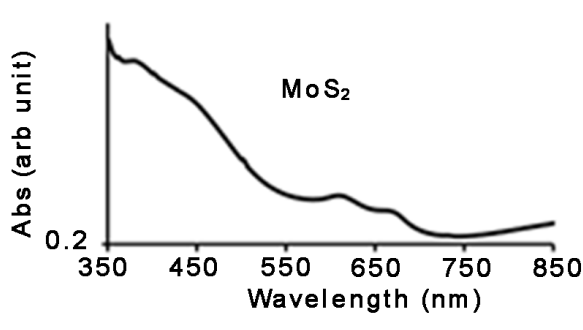

(b)

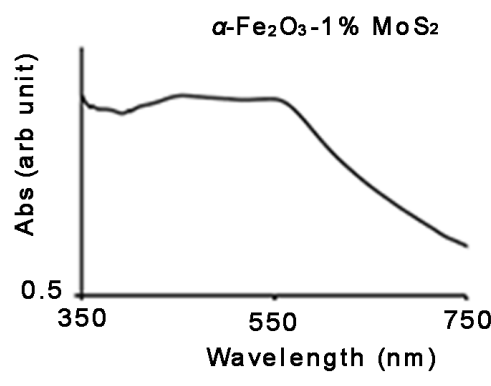

(e)

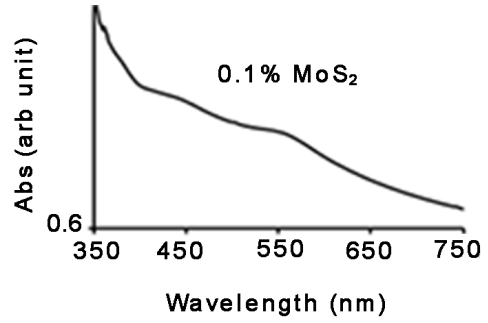

(c)

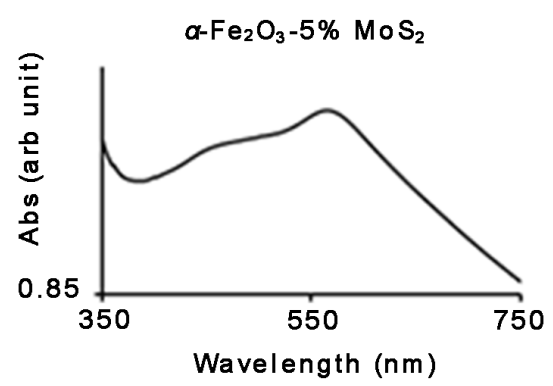

(f)

Figure 2. UV-vis absorption spectra of $\mathrm{MoS}_{2}$ with $\alpha$-hematite nanocomposite.

pristine $\alpha-\mathrm{Fe}_{2} \mathrm{O}_{3}$ similar to shown in literature. Figure 2(b) shows the characteristics absorption bands 388, 453, 618 and $679 \mathrm{~nm}$ for the $\mathrm{MoS}_{2}$ nanomaterial film on glass plates. Figures 2 (c)-(f) shows the UV-vis absorption spectra for $\mathrm{MoS}_{2}$ doped in different percentage $(0.1 \%, 0.2 \%, 1 \%$ and $5 \%)$ with $\alpha-\mathrm{Fe}_{2} \mathrm{O}_{3}$ nanomaterial. Figure 2(c) shows the absorption bands at 282, 454, $463 \mathrm{~nm}$. Figure 2(d) shows the absorption bands at 446 and $565 \mathrm{~nm}$. The distinct peaks can be seen at 382, 461 and $570 \mathrm{~nm}$. Figure 2(e) absorbs the UV-vis band at 382, 456 and $559 \mathrm{~nm}$ whereas Figure 2(f) shows the absorption band at 382, 459 and 572 $\mathrm{nm}$. There is a blue shift as an increase of $\mathrm{MoS}_{2}$ in $\alpha-\mathrm{Fe}_{2} \mathrm{O}_{3}$ [36]. However, the band observed for $0.1 \% \mathrm{MoS}_{2}$ doping is shifted at $572 \mathrm{~nm}$ in 5\% MoS2 doping in $\alpha-\mathrm{Fe}_{2} \mathrm{O}_{3}$ nanomaterial. Suchresults are consistent with the result shown of transition composite metal ions [37]. The UV-vis spectra of the composite hematite have been estimated to be $2.17 \mathrm{eV}$ for the band at $572 \mathrm{~nm}$.

\subsection{XRD Studies}

The crystalline structure of $\mathrm{MoS}_{2}-\alpha-\mathrm{Fe}_{2} \mathrm{O}_{3}$ was investigated by using Powder X-ray diffraction (XRD), model PANalytical X'Pert Pro MRD system, with $\mathrm{Cu} \mathrm{K}$ $\alpha$ radiation (wavelength $=1.5442 \AA$ ) operated at $40 \mathrm{kV}$ and $40 \mathrm{~mA}$. Figure 3 shows X-ray diffraction curves for different percentage of $\operatorname{MoS}_{2}(0.1 \%, 0.2 \%$, $0.5 \%, 1 \%, 2 \%$, and $5 \%)$ to $\alpha-\mathrm{Fe}_{2} \mathrm{O}_{3} ; \alpha-\mathrm{Fe}_{2} \mathrm{O}$ has polycrystalline structure as revealed from XRD pattern. The diffraction common peaks in $\mathrm{MoS}_{2}-\alpha-\mathrm{Fe}_{2} \mathrm{O}_{3}$ nanocomposite at different percentage of $\mathrm{MoS}_{2}$ displays bands at $31.2^{\circ}, 33.2^{\circ}, 37.5^{\circ}$, $40.9^{\circ}, 49.5^{\circ}, 54.1^{\circ}, 62.2^{\circ}$, and $64.2^{\circ}$ which can be indexed to (012), (104), (110), (113), (024), (116), (214), and (300) for crystal planes of hexagonal iron oxide [8]. It is clear from strong and sharp diffraction peaks that $\mathrm{Fe}_{2} \mathrm{O}_{3}$ is well crystallized 


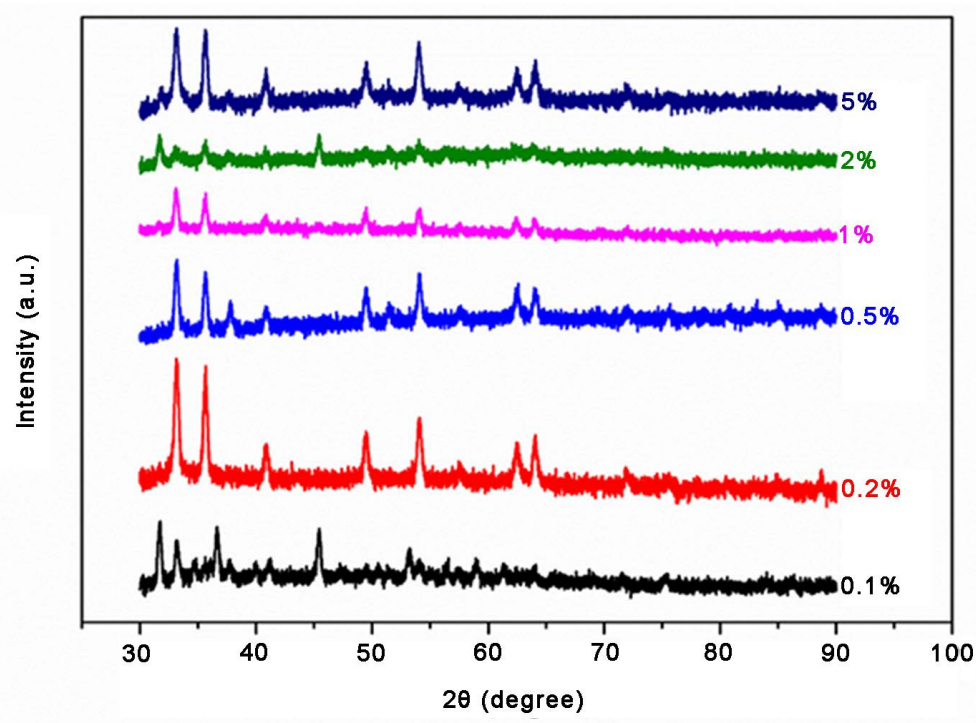

Figure 3. X-ray diffraction pattern of $\mathrm{MoS}_{2}$ with $\alpha$-hematite nanocomposite.

in the synthesis process for all percentage of $\mathrm{MoS}_{2}$ in $\alpha-\mathrm{Fe}_{2} \mathrm{O}_{3}$ [38]. The peak at $54.1^{\circ}$ is due to the presence of $\mathrm{MoS}_{2}$ in $\mathrm{MoS}_{2}-\alpha-\mathrm{Fe}_{2} \mathrm{O}_{3}$-structure.

\subsection{FTIR Studies}

Perkin Elmer spectrum one was utilized to study FTIR spectroscopy of various samples of $\mathrm{MoS}_{2}-\alpha-\mathrm{Fe}_{2} \mathrm{O}_{3}$-nanocomposite. The $\mathrm{MoS}_{2}-\alpha-\mathrm{Fe}_{2} \mathrm{O}_{3}$-nanocomposite was mixed with $\mathrm{KBr}$, the pellets were made using the hydraulic press, and the samples were measured using the transmission mode from 400 to $4000 \mathrm{~cm}^{-1}$. FTIR spectra of $\mathrm{MoS}_{2}-\alpha-\mathrm{Fe}_{2} \mathrm{O}_{3}$ shows the change of percentage of $\mathrm{MoS}_{2}$ doping with $\alpha-\mathrm{Fe}_{2} \mathrm{O}_{3}$ with Curve $1 \%$ to $5 \%$, Curve $2 \%$ to $0.2 \%$, Curve $3 \%$ to $2 \%$, Curve 4 to $1 \%$, Curve $5 \%$ to $0.5 \%$, and Curve $6 \%$ to $0.1 \%$ of $\mathrm{MoS}_{2}$ in $\mathrm{MoS}_{2}-\alpha-\mathrm{Fe}_{2} \mathrm{O}_{3}$ in shown in Figure 4. The infrared bands of each $\mathrm{MoS}_{2}$ doping to $\alpha-\mathrm{Fe}_{2} \mathrm{O}_{3}$ are shown in Table 2.

The hydroxyl $(\mathrm{OH})$ groups in $\alpha-\mathrm{Fe}_{2} \mathrm{O}_{3}$ is related to infrared band at $3414 \mathrm{~cm}^{-1}$. The band at $1642 \mathrm{~cm}^{-1}$ is due to $v(\mathrm{OH})$ stretching. The band at $562 \mathrm{~cm}^{-1}$ is due to Fe-O vibration mode in $\mathrm{Fe}_{2} \mathrm{O}_{3}$. The band at $620-654$ and $474-512$ are related to the lattice defects in $\mathrm{Fe}_{2} \mathrm{O}_{3}$ [39] [40]. The infrared band at $474-512 \mathrm{~cm}^{-1}$ is due to stretching vibration depicting the presence of $\mathrm{MoS}_{2}$ in the $\mathrm{MoS}_{2}-\alpha-\mathrm{Fe}_{2} \mathrm{O}_{3}$ structure. The doping of $0.1 \%$ to $5 \%$ of $\mathrm{MoS}_{2}$ shifts the infrared band from 512 $\mathrm{cm}^{-1}$ to $474 \mathrm{~cm}^{-1}$. The band at $474 \mathrm{~cm}^{-1}$ is the band observed for exfoliated $\mathrm{MoS}_{2}$ nanosheets revealing that maximum doping in $\mathrm{MoS}_{2}-\alpha-\mathrm{Fe}_{2} \mathrm{O}_{3}$ structure [41].

\subsection{SEM Studies}

The scanning electron microscopy (SEM) of various $\mathrm{MoS}_{2}-\alpha-\mathrm{Fe}_{2} \mathrm{O}_{3}$ samples were measured using FE-SEM, S-800, Hitachi. Figure 5 shows SEM images of $\mathrm{MoS}_{2}-\alpha-\mathrm{Fe}_{2} \mathrm{O}_{3}$ nanomaterials which consisted of different percentages from 0.1 to $5 \% \mathrm{MoS}_{2}$ to $\mathrm{Fe}_{2} \mathrm{O}_{3}$ in $\mathrm{MoS}_{2}-\alpha-\mathrm{Fe}_{2} \mathrm{O}_{3}$. SEM images reveals that the morphology 
Table 2. The infrared bands of each $\mathrm{MoS}_{2}$ doping to $\alpha-\mathrm{Fe}_{2} \mathrm{O}_{3}$.

\begin{tabular}{rc}
\hline $4 . \mathrm{MoS}_{2}$ & Wavenumber $\left(\mathrm{cm}^{-1}\right)$ \\
\hline $5 \%$ & $474,562,620,1136,1193,1472,1642,2858,2924,3436$ \\
$2 \%$ & $484,562,620,1136,1193,1472,1642,2858,2924,3436$ \\
$1 \%$ & $474,570,640,1006,1134,1388,1470,1670,2854,2924,3436$ \\
$0.5 \%$ & $458,554,644,802,898,1042,1386,1468,1634,2856,2922,3438$, \\
$0.1 \%$ & $512,522,654,802,1114,1396,1434,1666,2836,2952,3448$ \\
\hline
\end{tabular}

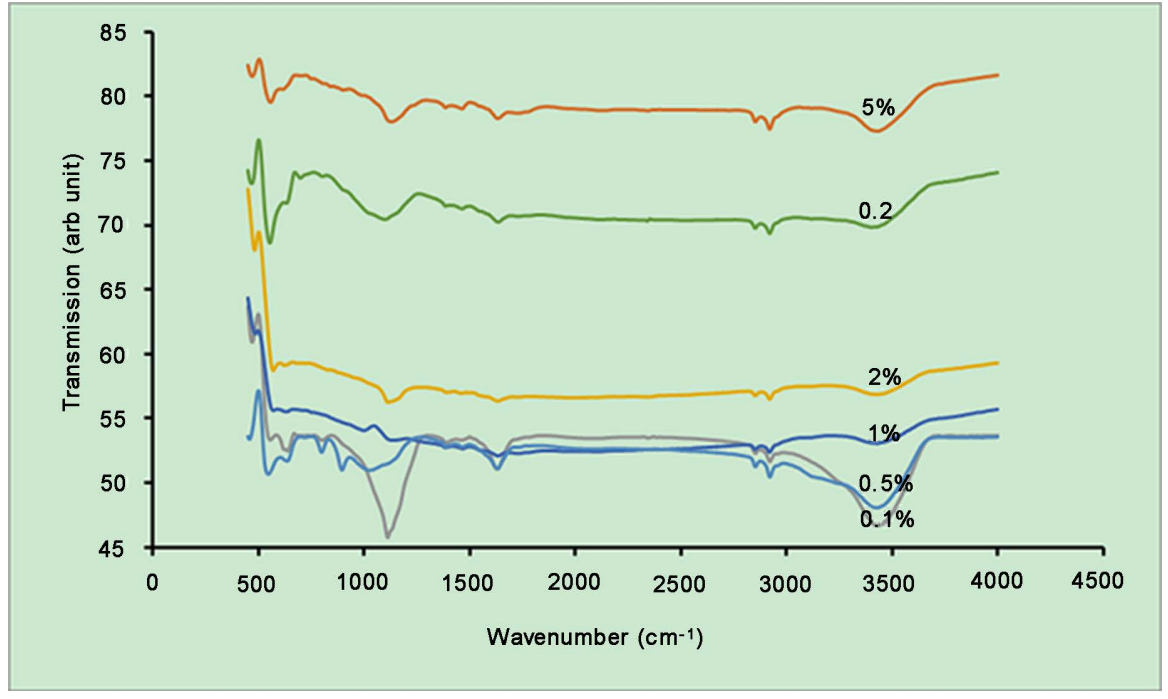

Figure 4. FTIR spectra of $\mathrm{MoS}_{2}$ with $\alpha$-hematite nanocomposite. Each curve $\mathrm{MoS}_{2}$ doping with $\mathrm{Fe}_{2} \mathrm{O}_{3}$ is given as: Curve $1=5 \% \mathrm{MoS}_{2}$, Curve $2=0.2 \% \mathrm{MoS}_{2}-\mathrm{Fe}_{2} \mathrm{O}_{3}$, and Curve $3=2 \%$ $\mathrm{MoS}_{2}-\mathrm{Fe}_{2} \mathrm{O}_{3}$, Curve $4=1 \% \mathrm{MoS}_{2}-\mathrm{Fe}_{2} \mathrm{O}_{3}$, Curve $5=0.5 \% \mathrm{MoS}_{2}-\mathrm{Fe}_{2} \mathrm{O}_{3}$ and Curve $6=0.1 \%$ $\mathrm{MoS}_{2}-\mathrm{Fe}_{2} \mathrm{O}_{3}$.

$\mathrm{MoS}_{2}-\alpha-\mathrm{Fe}_{2} \mathrm{O}_{3}$ resembles blooming flower-like nanoparticles. The blooming flower-like morphology is a result of doping $\mathrm{MoS}_{2}$ with $\alpha-\mathrm{Fe}_{2} \mathrm{O}_{3}$ [42]. The images reveal that the size of the particle changes with the increase of $\mathrm{MoS}_{2}$ doping from $0.1 \%$ to $5 \%$ in $\mathrm{MoS}_{2}-\alpha-\mathrm{Fe}_{2} \mathrm{O}_{3}$ nanomaterial. Besides, it is difficult to differentiate simple $\alpha$ - $\mathrm{Fe}_{2} \mathrm{O}_{3}$ nanoparticles from $\mathrm{MoS}_{2}$ nanosheets; this shows a strong interface formation between $\mathrm{Fe}_{2} \mathrm{O}_{3}$ and $\mathrm{MoS}_{2}$ in $\mathrm{MoS}_{2}-\alpha-\mathrm{Fe}_{2} \mathrm{O}_{3}$ nanomaterial [43].

\subsection{Raman Spectroscopy}

The Raman spectrum is measured which is also a rapid and nondestructive surface characterization technique to probe the vibrational properties of bonding of $\mathrm{MoS}_{2}$ to $\mathrm{Fe}_{2} \mathrm{O}_{3}$ in $\mathrm{MoS}_{2}-\alpha-\mathrm{Fe}_{2} \mathrm{O}_{3}$ nanomaterial. Figure 6 shows the Raman spectra of $\mathrm{MoS}_{2}-\alpha-\mathrm{Fe}_{2} \mathrm{O}_{3}$ film excited by $532 \mathrm{~nm}$ laser [44]. The Raman shift at 532 $\mathrm{cm}^{-1}$ resonates with the electronic transition in ring structures for aromatic clustering processes in $\mathrm{sp}^{2}$-dominated particles. The shift associated at 374 and $417 \mathrm{~cm}^{-1}$ are due to in-plane vibrational $\left(\mathrm{E}_{2 \mathrm{~g} 1}\right)$ and the out-of-plane vibrational $\left(\mathrm{A}_{1 \mathrm{~g}}\right)$ modes. The enhanced $\mathrm{MoS}_{2}$ is indicative of energy difference between Raman shifts due to $\mathrm{MoS}_{2}$ content in $\mathrm{MoS}_{2}-\alpha-\mathrm{Fe}_{2} \mathrm{O}_{3}$ nanomaterial. 

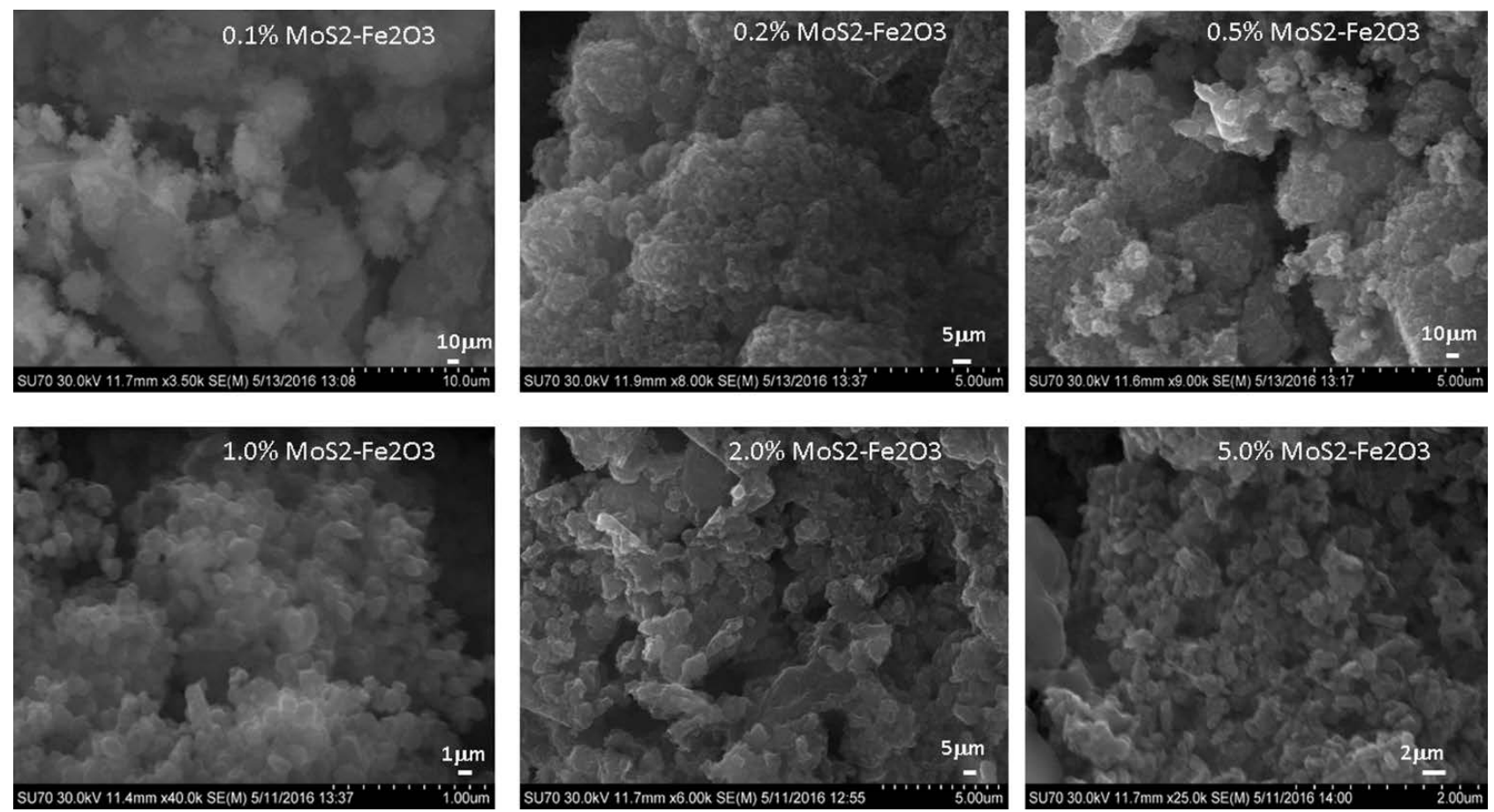

Figure 5. Scanning electron micrographs (SEM) of $\mathrm{MoS}_{2}$ with $\alpha$-hematite nanocomposite. The percentage of $\mathrm{MoS}_{2}$ with $\alpha$-hematite nanocomposite is shown in Figure 5.

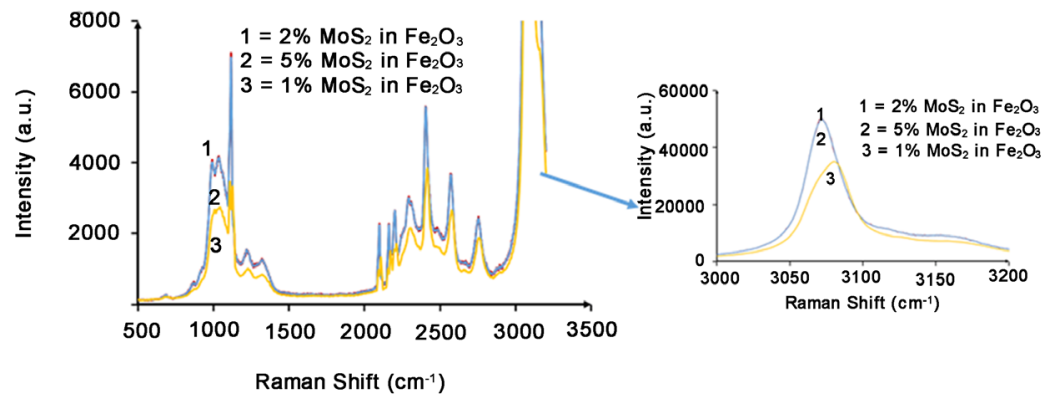

(a)

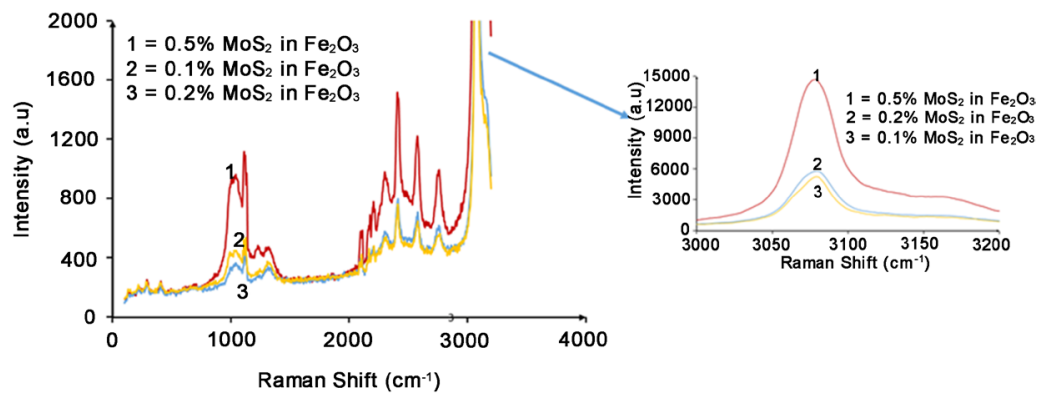

(b)

Figure 6. Raman spectra of $\mathrm{MoS}_{2}-\alpha-\mathrm{Fe}_{2} \mathrm{O}_{3}$ film sample and ITO substrate as various percentage of $\mathrm{MoS}_{2}$ as shown in figures.

\subsection{Particle Analysis}

The Zetasizer Nano particle analyzer range model was used to measure the average particle size of various $\mathrm{MoS}_{2}-\alpha-\mathrm{Fe}_{2} \mathrm{O}_{3}$ samples. Initially, the $\mathrm{MoS}_{2}-\alpha-\mathrm{Fe}_{2} \mathrm{O}_{3}$ 
nanomaterial was dispersed in water and ultra-sonicated to have aggregated free colloidal sample. Figure 7 shows the particle size of $\mathrm{MoS}_{2}-\alpha-\mathrm{Fe}_{2} \mathrm{O}_{3}$ as a function of $\mathrm{MoS}_{2}$ doping in $\alpha-\mathrm{Fe}_{2} \mathrm{O}_{3}$. The average particle size in liquid sample ranges from $459 \mathrm{~nm}(0.1 \%)$ to $825 \mathrm{~nm}$ for $(5 \%)$ do pant of $\mathrm{MoS}_{2}$ respectively. Although these particles are small, there are few particles which are larger than 5 microns. These larger particles that can be detected through SEM measurement are a result of aggregation. The average size of particles is important for the fabrication of the electrodes from the particles. This information of nanomaterial dispersion of $\mathrm{MoS}_{2}-\alpha-\mathrm{Fe}_{2} \mathrm{O}_{3}$ can be exploited for the electrode fabrication or other applications.

\subsection{Electrochemical Studies}

\subsubsection{Cyclic Voltammetry}

The electrochemical measurements on various $\mathrm{MoS}_{2}-\alpha-\mathrm{Fe}_{2} \mathrm{O}_{3}$ electrodes were measured from electrochemical workstation (Volta lab). The electrochemical set-up was adopted similar to our earlier studies on hybrid films [45] [46]. Figure 8 shows the cyclic voltammetry $(\mathrm{CV})$ of $1 \% \mathrm{MoS}_{2}-\alpha-\mathrm{Fe}_{2} \mathrm{O}_{3}$ in $1 \mathrm{M} \mathrm{NaOH}$ as working electrode, platinum $(\mathrm{Pt})$ as counter and $\mathrm{Ag} / \mathrm{AgCl}$ as reference electrode in three electrodes based electrochemical cell. The continuous increase of CV current was observed with an increase in function of scan rate. The presence of $\mathrm{MoS}_{2}$ ions induces the electrochemical properties and $1.3 \mathrm{~V}$ can be seen as oxidation potential of water that is less than the Aluminum-doped from our previous studies [30].

The CV is shown in Figure 9 with application of light simulated for solar radiation. However, with the scan rate of $100 \mathrm{mV} / \mathrm{sec}$, there was a maximum photocurrent absorbed for $\mathrm{MoS}_{2}-\alpha-\mathrm{Fe}_{2} \mathrm{O}_{3}$ film. The diffusion coefficient was

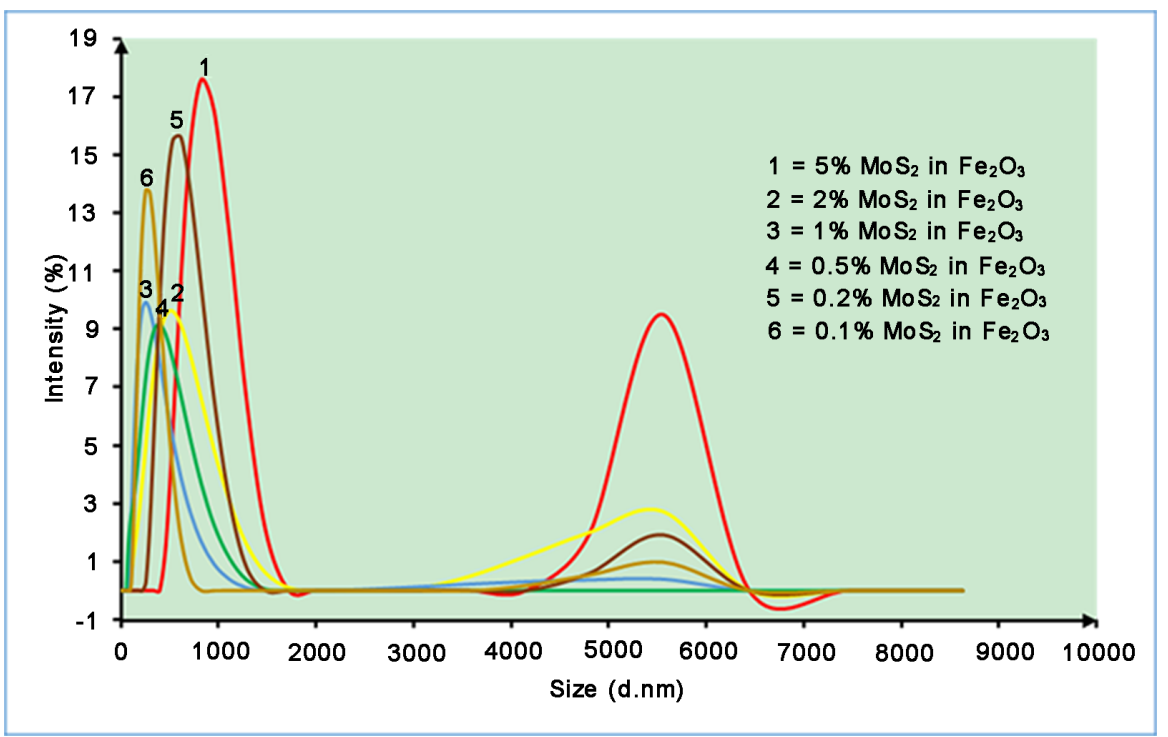

Figure 7. The particle size measurement of $\mathrm{MoS}_{2}-\alpha-\mathrm{Fe}_{2} \mathrm{O}_{3}$ nanocomposite materials as a function of $\mathrm{MoS}_{2}$ dopant. 
$1 \% \mathrm{MoS}_{2}$ in $\mathrm{\alpha}-\mathrm{Fe}_{2} \mathrm{O}_{3}$ without light

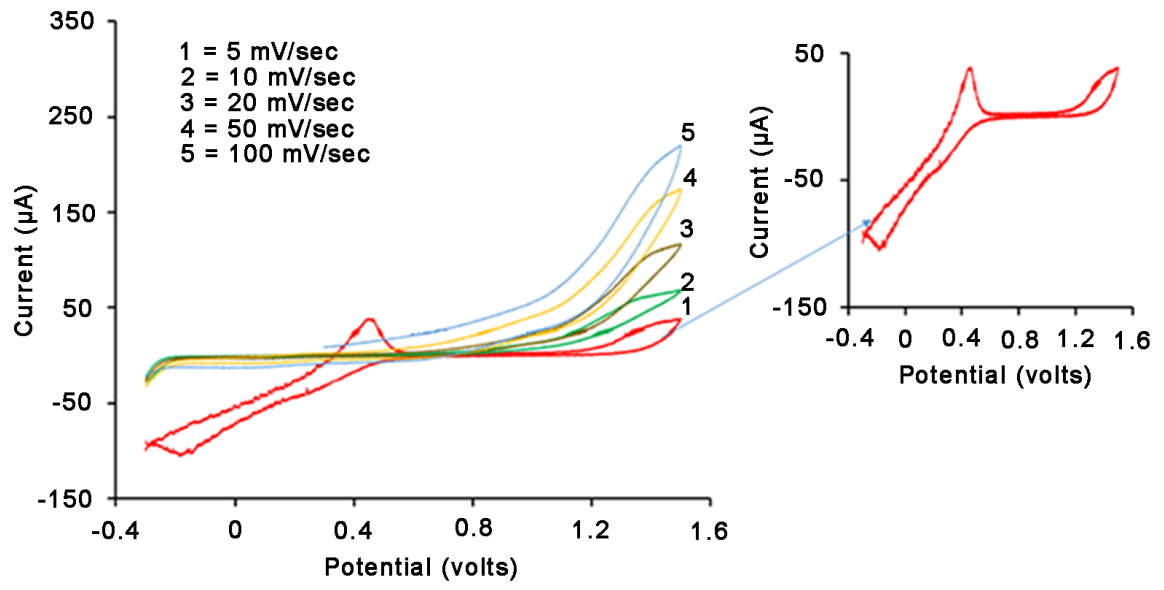

Figure 8. The cyclic voltammetry of $1 \% \mathrm{MoS}_{2}$ with $\mathrm{Fe}_{2} \mathrm{O}_{3}$ nanocomposite without light in $1 \mathrm{M} \mathrm{NaOH}$ in three electrodes where platinum as reference and $\mathrm{Ag} / \mathrm{AgCl}$ as reference electrode.

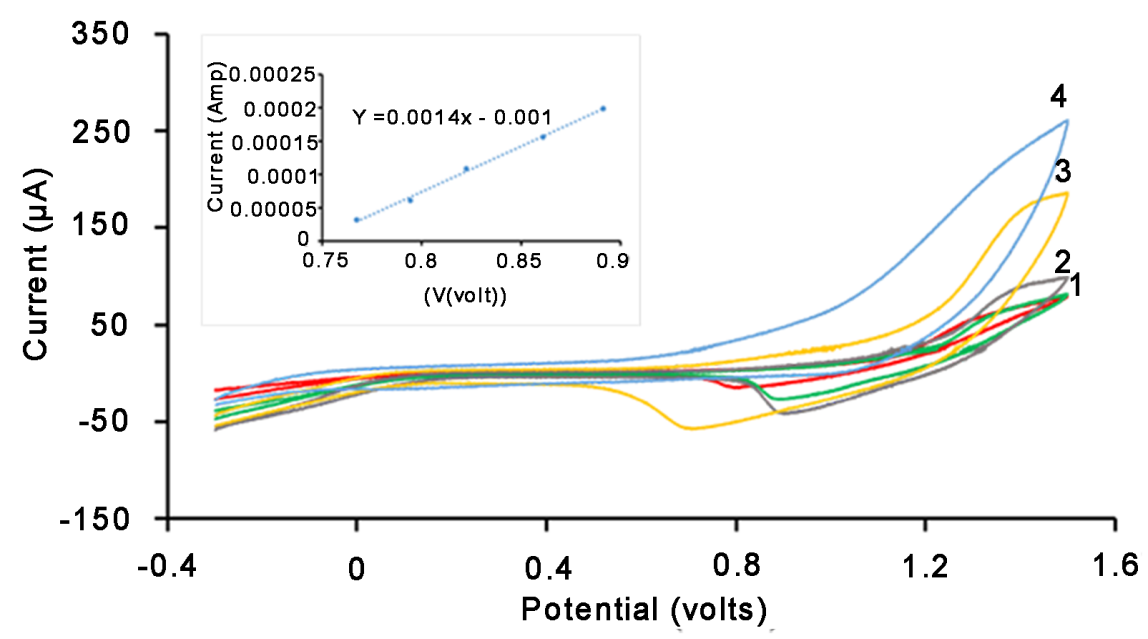

Figure 9. The cyclic voltammetry of $1 \% \mathrm{MoS}_{2}$ with $\mathrm{Fe}_{2} \mathrm{O}_{3}$ nanocomposite with light in 1 $\mathrm{M} \mathrm{NaOH}$ in three electrodes where platinum as reference and $\mathrm{Ag} / \mathrm{AgCl}$ as reference electrode.

calculated by using peak current for a reversible cyclic voltammetry is given by the Randles-Sevcik equation (Equation (2)).

$$
I_{P}=\left(2.69 \times 10^{5}\right) n^{3 / 2} A C D^{1 / 2} v^{1 / 2}
$$

where:

$$
\begin{aligned}
& n=\text { number of electrons } \\
& A=\text { electrode area }\left(\mathrm{cm}^{2}\right) \\
& C=\text { concentration }\left(\mathrm{mole} / \mathrm{cm}^{3}\right) \\
& D=\text { diffusion coefficient }\left(\mathrm{cm}^{2} / \mathrm{s}\right) \\
& v=\text { potential scan rate }(\mathrm{V} / \mathrm{s}) \\
& I_{p}=\text { current. }
\end{aligned}
$$

The diffusion coefficient has been estimated to be $0.24 \times 10^{-16} \mathrm{~cm}^{2} / \mathrm{s}$. 


\subsubsection{Chronoamperometry Study}

We made an attempt to deposit $\mathrm{MoS}_{2}-\alpha-\mathrm{Fe}_{2} \mathrm{O}_{3}$ film on ITO coated glass substrates uniformly using the homogenous paste obtained using acetic acid. The thickness of $\mathrm{MoS}_{2}-\alpha-\mathrm{Fe}_{2} \mathrm{O}_{3}$ was around $30 \mu \mathrm{m}$. Figure 10(a) \& Figure 10(b) shows the chronoamperometry study of two electrodes cell consisting of $\mathrm{MoS}_{2}-\alpha-\mathrm{Fe}_{2} \mathrm{O}_{3}$ film as working and steel as counter in various concentrations $(0.010 .1,1 \mathrm{M})$ of $\mathrm{NaOH}$ based electrolyte. The potential from $-1000 \mathrm{mV}$ to $1500 \mathrm{mV}$ was applied, and the chronoamperometry photocurrent was studied. Figure 10(a) \& Figure 10 (b) shows the chronoamperometry photocurrent plot with $\mathrm{t}^{-1 / 2}$ for oxidation and reduction processes for $\mathrm{MoS}_{2}-\alpha-\mathrm{Fe}_{2} \mathrm{O}_{3}$ film. The rise of photocurrent showed a linear relationship with $\mathrm{t}^{-1 / 2}$ due to excitation of light. The current transient was different from the excitation of light. The diffusion-controlled photocurrent is calculated using Cottrell equation in Equation (3) [47] [48] [49].

$$
i=\left[n F A D^{\frac{1}{2}} C\right] /\left[\pi t^{\frac{1}{2}}\right]
$$

where:

$n=$ the electron participating in the reaction

$F=$ the faraday constant

$A=$ the area of the electrode

$i=$ the transient current

$D=$ the diffusion coefficient

$C=$ the concentration of the electrolyte

The $\mathrm{D}$ has been estimated to be $1.057 \times 10^{-14} \mathrm{~cm}^{2} / \mathrm{sec}$.

\subsubsection{Impedance Study}

Figure 11(a) and Figure 11(b) show the Nyquist plot in $1 \mathrm{M} \mathrm{NaOH}$ without and with light irradiation in $\mathrm{MoS}_{2}-\alpha-\mathrm{Fe}_{2} \mathrm{O}_{3}$ film in a photoelectrochemical

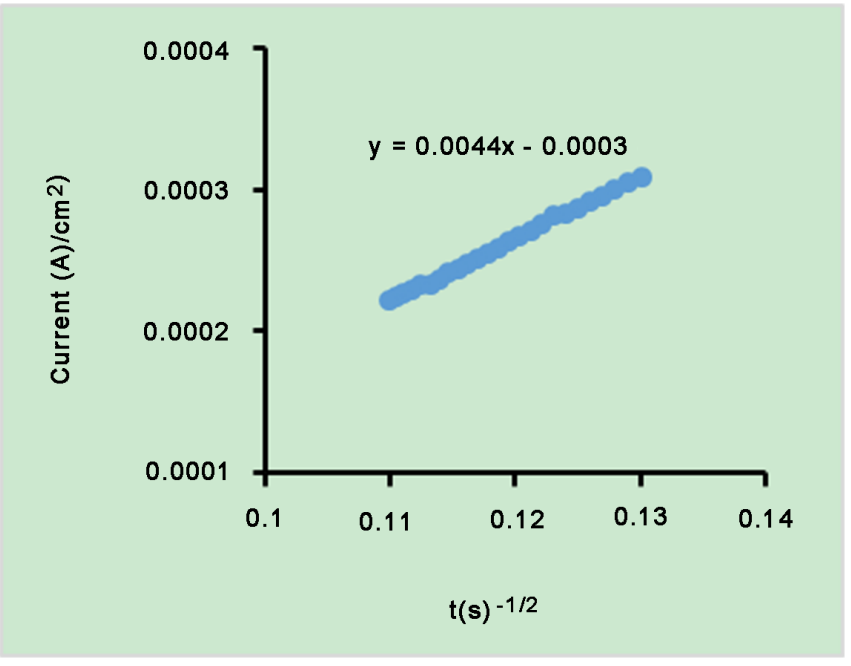

(a)

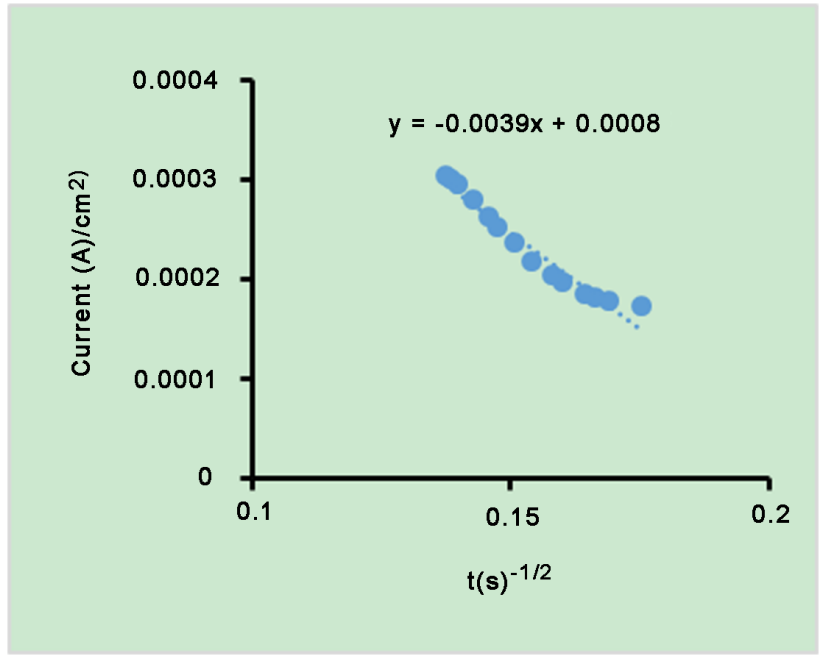

(b)

Figure 10. The chronoamperometry photocurrent plot with $\mathrm{t}(\mathrm{s})^{-1 / 2}$ for oxidation and reduction processes for $\mathrm{MoS}_{2}-\alpha$-Fe $\mathrm{O}_{3}$ film. 


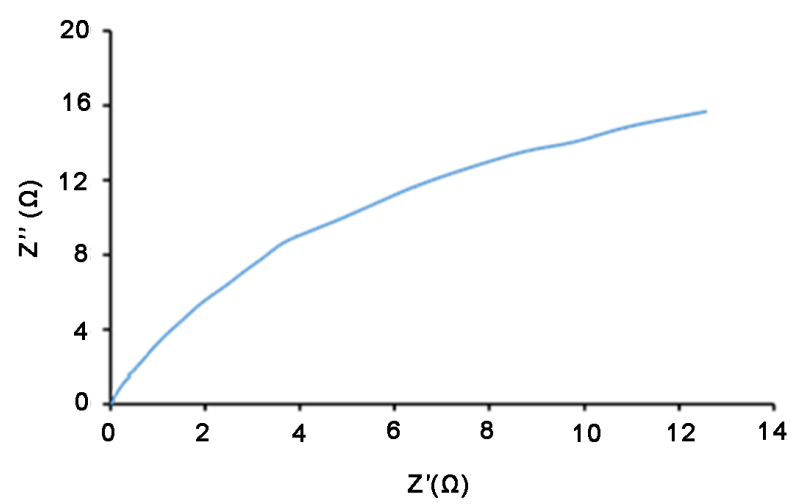

(a)

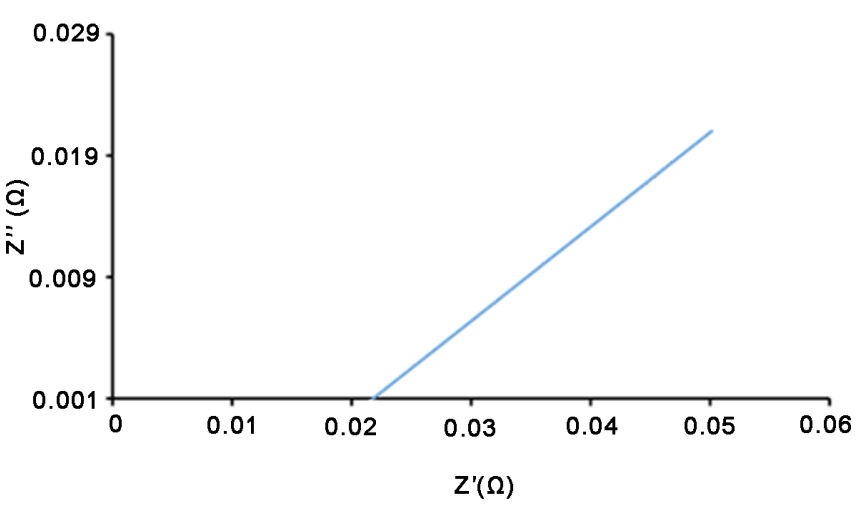

(b)

Figure 11. Nyquist plot of $\mathrm{MoS}_{2}-\alpha-\mathrm{Fe}_{2} \mathrm{O}_{3}$ film in $1 \mathrm{M} \mathrm{HCl}$ in photoelectrochemical cell without (a) and with (b) light irradiation.

set-up. The change in the impedance value has been observed for real and imaginary without light irradiation as shown in Figure 11(a) and Figure 11(b). The photocurrent is able to make process more conducting in presence of light.

\subsubsection{Half Sweep Potential}

Figure 12 shows the half sweep potential with and without light for both aluminum doped- $\alpha-\mathrm{Fe}_{2} \mathrm{O}_{3}$ and $\mathrm{MoS}_{2}-\alpha-\mathrm{Fe}_{2} \mathrm{O}_{3}$. Our previous study on aluminum doping has shown the photocurrent to be $35 \mu \mathrm{A}$ whereas for the same type of electrode for $\mathrm{MoS}_{2}-\alpha-\mathrm{Fe}_{2} \mathrm{O}_{3}$ showed the current to be $150 \mu \mathrm{A}$. Schottky type current-voltage is experienced for both aluminum doped as well as $\mathrm{MoS}_{2}-\alpha-\mathrm{Fe}_{2} \mathrm{O}_{3}$ based electrode in photoelectrochemical cell.

\subsection{Schematic of $\mathrm{MoS}_{2}-\alpha-\mathrm{Fe}_{2} \mathrm{O}_{3}$ Reaction Process}

A schematic was drawn to understand the effect of $\mathrm{MoS}_{2}$ with $\alpha-\mathrm{Fe}_{2} \mathrm{O}_{3}$. The schematic of hydrogen production using $\mathrm{MoS}_{2}$-composite $\alpha-\mathrm{Fe}_{2} \mathrm{O}_{3}$ photocatalyst in $1 \mathrm{M} \mathrm{NaOH}$ is shown in Figure 13. The bandgap of $\mathrm{MoS}_{2}$ varies from 1.2 - 1.9 $\mathrm{eV}$, whereas the band gap of $\alpha-\mathrm{Fe}_{2} \mathrm{O}_{3}$ is $2.1 \mathrm{eV}$. It was estimated the bandgap of $\mathrm{MoS}_{2}$-composite $\alpha$ - $\mathrm{Fe}_{2} \mathrm{O}_{3}$ in range of 1.94 to $2.40 \mathrm{eV}$ based on UV-vis measurements, which is well in the region of visible light. $\mathrm{MoS}_{2}$ doping also increased the conductivity of the samples. The schematic in Figure 12 shows the photogenerated electrons from conduction band of $\mathrm{MoS}_{2}$ is transferred to conduction band (CB) of $\alpha-\mathrm{Fe}_{2} \mathrm{O}_{3}$ whereas holes from $\alpha-\mathrm{Fe}_{2} \mathrm{O}_{3}$ e are transferred to valence band (VB) of $\mathrm{MoS}_{2}$. This enhances the photocatalytic activity of $\mathrm{MoS}_{2}$ composite with $\alpha-\mathrm{Fe}_{2} \mathrm{O}_{3}$ in $\mathrm{MoS}_{2}-\alpha-\mathrm{Fe}_{2} \mathrm{O}_{3}$ nanomaterial-based electrode.

\section{Conclusions}

The synthesized $\mathrm{MoS}_{2}-\alpha-\mathrm{Fe}_{2} \mathrm{O}_{3}$ observed the shift in the band gap to $2.17 \mathrm{eV}$ with $\mathrm{MoS}_{2}$ doping. There is a marked change in the band due to $\mathrm{MoS}_{2}$ doping in $\alpha$ - $\mathrm{Fe}_{2} \mathrm{O}_{3}$. The increase of $\mathrm{MoS}_{2}$ dominated the structure as marked from SEM measurements. The photocurrent can be clearly distinguishable with and without light irradiation through various electrochemical studies on $\mathrm{MoS}_{2}-\alpha-\mathrm{Fe}_{2} \mathrm{O}_{3}$ 

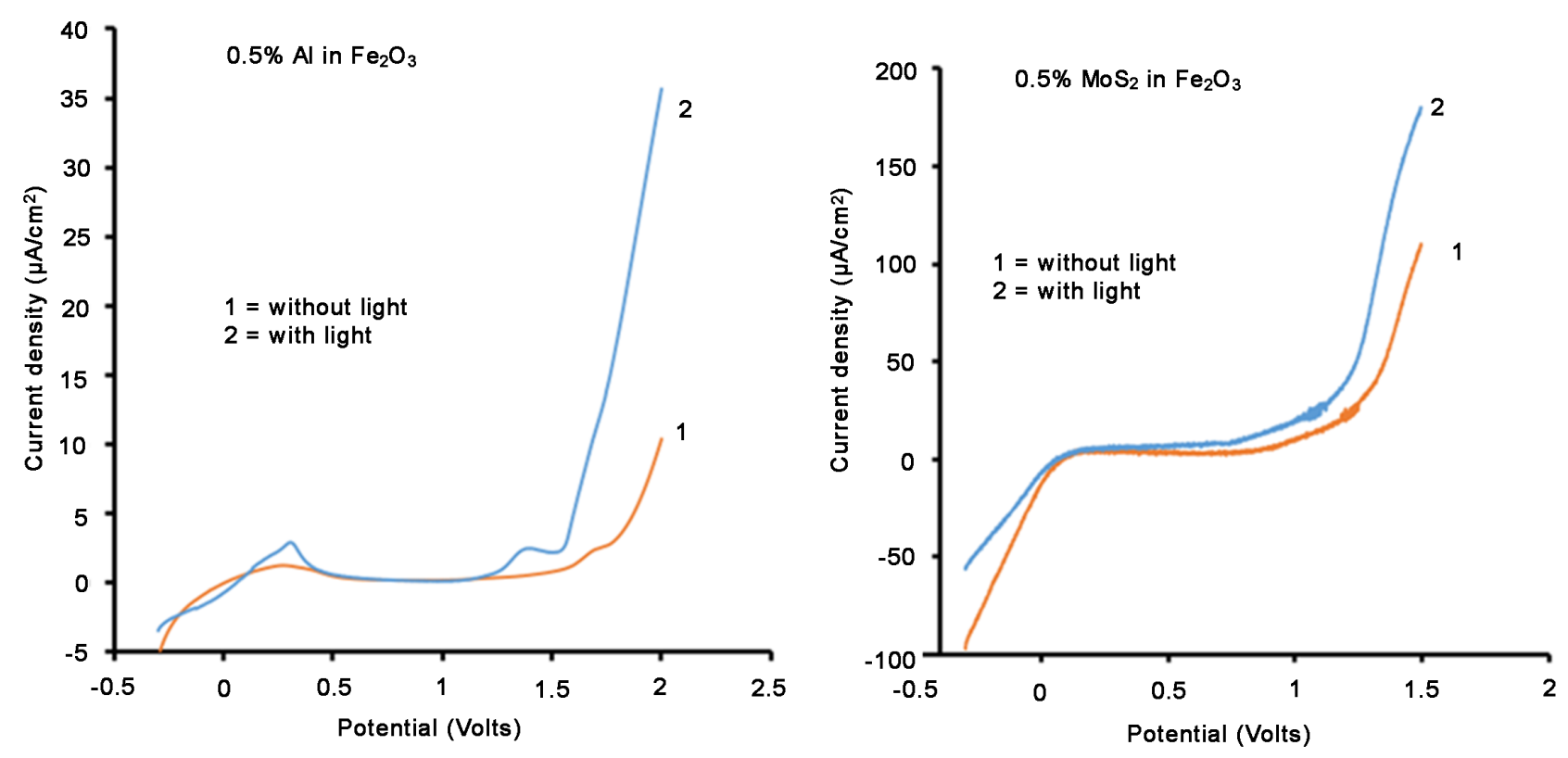

Figure 12. Half sweep potential with and without light for Aluminum doped- $\alpha$ - $\mathrm{Fe}_{2} \mathrm{O}_{3}$ and $\mathrm{MoS}_{2}-\alpha-\mathrm{Fe}_{2} \mathrm{O}_{3}$ film with and without light exposure.

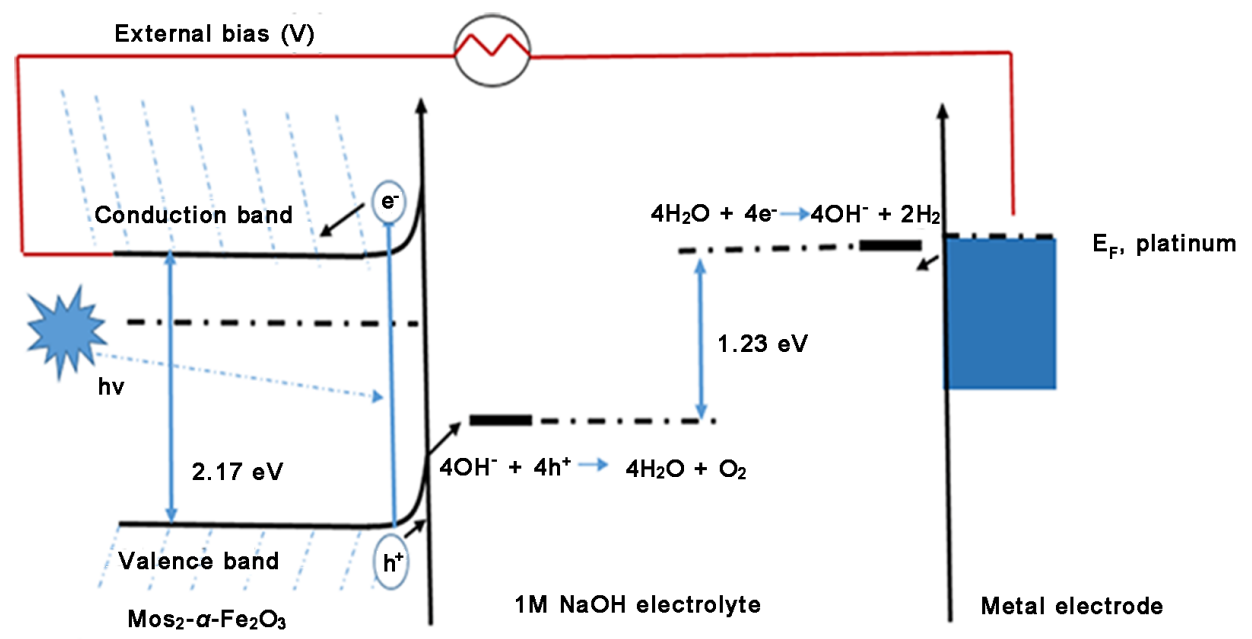

Figure 13. The schematic of hydrogen production using $\mathrm{MoS}_{2}$-composite $\alpha-\mathrm{Fe}_{2} \mathrm{O}_{3}$ photocatalyst in $1 \mathrm{M} \mathrm{NaOH}$.

nanomaterial. The enhanced photocurrent is observed with $\mathrm{MoS}_{2}$ doping in $\mathrm{MoS}_{2}-\alpha-\mathrm{Fe}_{2} \mathrm{O}_{3}$ nanomaterial. The $\mathrm{MoS}_{2}-\alpha-\mathrm{Fe}_{2} \mathrm{O}_{3}$ nanomaterial thin film has the potential to produce hydrogen using a PEC water splitting process that could have renewable energy applications. Our future work is based on the use of $\mathrm{MoS}_{2}-\alpha-\mathrm{Fe}_{2} \mathrm{O}_{3}$ as $\mathrm{n}$-type in $\mathrm{p}-\mathrm{n}$ photoelectrochemical studies for efficient water splitting applications.

\section{Acknowledgements}

The authors are grateful to Sina and Mike McCrory for their help in X-ray diffraction, EDS and SEM measurements. 


\section{References}

[1] Wheeler, D.A., Wang, G., Ling, Y., Li, Y. and Zhang, J.Z. (2012) Nanostructured Hematite: Synthesis, Characterization, Charge Carrier Dynamics, and Photoelectrochemical Properties. Energy \& Environmental Science, 5, 6682-6702. https://doi.org/10.1039/c2ee00001f

[2] Li, Y., Wang, H., Xie, L., Liang, Y., Hong, G. and Dai, H. (2011) $\mathrm{MoS}_{2}$ Nanoparticles Grown on Graphene: An Advanced Catalyst for the Hydrogen Evolution Reaction. Journal of the American Chemical Society, 133, 7296-7299. https://doi.org/10.1021/ja201269b

[3] Sivula, K., Le Formal, F. and Grätzel, M. (2011) Solar Water Splitting: Progress Using Hematite $\left(\alpha-\mathrm{Fe}_{2} \mathrm{O}_{3}\right)$ Photoelectrodes. ChemSusChem, 4, 432-449. https://doi.org/10.1002/cssc.201000416

[4] Hiralal, P., Saremi-Yarahmadi, S., Bayer, B.C., Wang, H., Hofmann, S., Wijayantha, K.U. and Amaratunga, G.A. (2011) Nanostructured Hematite Photoelectrochemical Electrodes Prepared by the Low Temperature Thermal Oxidation of Iron. Solar Energy Materials and Solar Cells, 95, 1819-1825. https://doi.org/10.1016/j.solmat.2011.01.049

[5] Ahn, H.-J., Yoon, K.-Y., Kwak, M.-J., Lee, J.-S., Thiyagarajan, P. and Jang, J.-H. (2015) $\mathrm{MoS}_{\mathrm{x}}$ Supported Hematite with Enhanced Photoelectrochemical Performance. Journal of Materials Chemistry A, 3, 21444-21450. https://doi.org/10.1039/C5TA06743J

[6] Hisatomi, T., Kubota, J. and Domen, K. (2014) Recent Advances in Semiconductors for Photocatalytic and Photoelectrochemical Water Splitting. Chemical Society Reviews, 43, 7520-7535. https://doi.org/10.1039/C3CS60378D

[7] Kim, J.Y., Magesh, G., Youn, D.H., Jang, J.-W., Kubota, J., Domen, K. and Lee, J.S. (2013) Single-Crystalline, Wormlike Hematite Photoanodes for Efficient Solar Water Splitting. Scientific reports, 3, 2681. https://doi.org/10.1038/srep02681

[8] Kment, S., Hubicka, Z., Krysa, J., Sekora, D., Zlamal, M., Olejnicek, J., Cada, M., Ksirova, P., Remes, Z. and Schmuki, P. (2015) On the Improvement of PEC Activity of Hematite Thin Films Deposited by High-Power Pulsed Magnetron Sputtering Method. Applied Catalysis B: Environmental, 165, 344-350. https://doi.org/10.1016/j.apcatb.2014.10.015

[9] Hisatomi, T., Dotan, H., Stefik, M., Sivula, K., Rothschild, A., Grätzel, M. and Mathews, N. (2012) Enhancement in the Performance of Ultrathin Hematite Photoanode for Water Splitting by an Oxide Underlayer. Advanced Materials, 24, 2699-2702. https://doi.org/10.1002/adma.201104868

[10] Ahn, H.-J., Kwak, M.-J., Lee, J.-S., Yoon, K.-Y. and Jang, J.-H. (2014) Nanoporous Hematite Structures to Overcome Short Diffusion Lengths in Water Splitting. Journal of Materials Chemistry A, 2, 19999-20003. https://doi.org/10.1039/C4TA04890C

[11] Satsangi, V.R., Kumari, S., Singh, A.P., Shrivastav, R. and Dass, S. (2008) Nanostructured Hematite for Photoelectrochemical Generation of Hydrogen. International Journal of Hydrogen Energy, 33, 312-318.

[12] Du, C., Yang, X., Mayer, M.T., Hoyt, H., Xie, J., McMahon, G., Bischoping, G. and Wang, D. (2013) Hematite-Based Water Splitting with Low Turn-On Voltages. Angewandte Chemie International Edition, 52, 12692-12695. https://doi.org/10.1002/anie.201306263

[13] Desai, J., Pathan, H., Min, S.-K., Jung, K.-D. and Joo, O.S. (2005) FT-IR, XPS and PEC Characterization of Spray Deposited Hematite Thin Films. Applied Surface Science, 252, 1870-1875. 
[14] Bassi, P.S., Wong, L.H. and Barber, J. (2014) Iron Based Photoanodes for Solar Fuel Production. Physical Chemistry Chemical Physics, 16, 11834-11842. https://doi.org/10.1039/c3cp55174a

[15] Tamirat, A.G., Rick, J., Dubale, A.A., Su, W.-N. and Hwang, B.-J. (2016) Using Hematite for Photoelectrochemical Water Splitting: A Review of Current Progress and Challenges. Nanoscale Horizons, 1, 243-267.

[16] Kumari, S., Tripathi, C., Singh, A.P., Chauhan, D., Shrivastav, R., Dass, S. and Satsangi, V.R. (2006) Characterization of Zn-Doped Hematite Thin Films for Photoelectrochemical Splitting of Water. Current Science, 91, 1062-1073.

[17] Jorand Sartoretti, C., Alexander, B.D., Solarska, R., Rutkowska, I.A., Augustynski, J. and Cerny, R. (2005) Photoelectrochemical Oxidation of Water at Transparent Ferric Oxide Film Electrodes. The Journal of Physical Chemistry B, 109, 13685-13692. https://doi.org/10.1021/jp051546g

[18] Kennedy, J.H. and Frese, K.W. (1978) Photooxidation of Water at $\alpha$ - $\mathrm{Fe}_{2} \mathrm{O}_{3}$ Electrodes. Journal of the Electrochemical Society, 125, 709-714. https://doi.org/10.1149/1.2131532

[19] Kleiman-Shwarsctein, A., Hu, Y.-S., Forman, A.J., Stucky, G.D. and McFarland, E.W. (2008) Electrodeposition of $\alpha-\mathrm{Fe}_{2} \mathrm{O}_{3}$ Doped with Mo or $\mathrm{Cr}$ as Photoanodes for Photocatalytic Water Splitting. The Journal of Physical Chemistry C, 112, 15900-15907. https://doi.org/10.1021/jp803775j

[20] Kleiman-Shwarsctein, A., Huda, M.N., Walsh, A., Yan, Y., Stucky, G.D., Hu, Y.-S., Al-Jassim, M.M. and McFarland, E.W. (2009) Electrodeposited Aluminum-Doped $\alpha-\mathrm{Fe}_{2} \mathrm{O}_{3}$ Photoelectrodes: Experiment and Theory. Chemistry of Materials, 22, 510-517. https://doi.org/10.1021/cm903135j

[21] Hu, Y.-S., Kleiman-Shwarsctein, A., Forman, A.J., Hazen, D., Park, J.-N. and McFarland, E.W. (2008) Pt-Doped $\alpha$ - $\mathrm{Fe}_{2} \mathrm{O}_{3}$ Thin Films Active for Photoelectrochemical Water Splitting. Chemistry of Materials, 20, 3803-3805. https://doi.org/10.1021/cm800144q

[22] Saremi-Yarahmadi, S., Wijayantha, K.U., Tahir, A.A. and Vaidhyanathan, B. (2009) Nanostructured $\alpha-\mathrm{Fe}_{2} \mathrm{O}_{3}$ Electrodes for Solar Driven Water Splitting: Effect of Doping Agents on Preparation and Performance. The Journal of Physical Chemistry C, 113, 4768-4778. https://doi.org/10.1021/jp808453z

[23] Kay, A., Cesar, I. and Grätzel, M. (2006) New Benchmark for Water Photooxidation by Nanostructured $\alpha-\mathrm{Fe}_{2} \mathrm{O}_{3}$ Films. Journal of the American Chemical Society, 128, 15714-15721. https://doi.org/10.1021/ja0643801

[24] Ding, Q., Meng, F., English, C.R., Cabán-Acevedo, M., Shearer, M.J., Liang, D., Daniel, A.S., Hamers, R.J. and Jin, S. (2014) Efficient Photoelectrochemical Hydrogen Generation using Heterostructures of Si and Chemically Exfoliated Metallic $\mathrm{MoS}_{2}$. Journal of the American Chemical Society, 136, 8504-8507.

[25] Yoon, K.-Y., Lee, J.-S., Kim, K., Bak, C.H., Kim, S.-I., Kim, J.-B. and Jang, J.-H. (2014) Hematite-Based Photoelectrochemical Water Splitting Supported by Inverse Opal Structures of Graphene. ACS Applied Materials \& Interfaces, 6, 22634-22639. https://doi.org/10.1021/am506721a

[26] Meng, F., Li, J., Cushing, S.K., Bright, J., Zhi, M., Rowley, J.D., Hong, Z., Manivannan, A., Bristow, A.D. and Wu, N. (2013) Photocatalytic Water Oxidation by Hematite/Reduced Graphene Oxide Composites. ACS Catalysis, 3, 746-751. https://doi.org/10.1021/cs300740e

[27] Liu, Y., Yu, Y.-X. and Zhang, W.-D. (2013) $\mathrm{MoS}_{2} / \mathrm{CdS}$ Heterojunction with High Photoelectrochemical Activity for $\mathrm{H}_{2}$ Evolution under Visible Light: The Role of 
$\mathrm{MoS}_{2}$. The Journal of Physical Chemistry C, 117, 12949-12957. https://doi.org/10.1021/jp4009652

[28] Alrobei, H. (2017) A-Hematite-Molybdenum Disulfide and Polyhexylthiophene (RRPHTh)-Nanodiamond (ND) Electrodes for Photoelectrochemical Applications. 3 rd International Conference on Smart Materials \& Structures, Orlando.

[29] Alrobei, H., Kumar, A. and Ram, M.K. (2015) Aluminum Doped $\alpha$-Hematite for Photoelectrochemical Applications. Research Day 2015 at USF College of Engineering, Tampa.

[30] Alrobei, H., Kumar, A. and Ram, M.K. (2017) Aluminum-A-Hematite Thin Films for Photoelectrochemical Applications. Surface Review and Letters (Communicated).

[31] Chen, Z., Cummins, D., Reinecke, B.N., Clark, E., Sunkara, M.K. and Jaramillo, T.F. (2011) Core-Shell $\mathrm{MoO}_{3}-\mathrm{MoS}_{2}$ Nanowires for Hydrogen Evolution: A Functional Design for Electrocatalytic Materials. Nano Letters, 11, 4168-4175. https://doi.org/10.1021/nl2020476

[32] Bonde, J., Moses, P.G., Jaramillo, T.F., Nørskov, J.K. and Chorkendorff, I. (2009) Hydrogen Evolution on Nano-Particulate Transition Metal Sulfides. Faraday Discussions, 140, 219-231. https://doi.org/10.1039/B803857K

[33] Kibsgaard, J., Chen, Z., Reinecke, B.N. and Jaramillo, T.F. (2012) Engineering the Surface Structure of $\mathrm{MoS}_{2}$ to Preferentially Expose Active Edge Sites for Electrocatalysis. Nature Materials, 11, 963-969. https://doi.org/10.1038/nmat3439

[34] Thurston, T. and Wilcoxon, J. (1999) Photooxidation of Organic Chemicals Catalyzed by Nanoscale $\mathrm{MoS}_{2}$. The Journal of Physical Chemistry B, 103, 11-17. https://doi.org/10.1021/jp982337h

[35] Han, S., Hu, L., Liang, Z., Wageh, S., Al-Ghamdi, A.A., Chen, Y. and Fang, X. (2014) One-Step Hydrothermal Synthesis of 2D Hexagonal Nanoplates of $\alpha$ - $\mathrm{Fe}_{2} \mathrm{O}_{3} /$ Graphene Composites with Enhanced Photocatalytic Activity. Advanced Functional Materials, 24, 5719-5727. https://doi.org/10.1002/adfm.201401279

[36] Alrobei, H., Kumar, A. and Ram, M.K. (2016) Doped A-Hematite with Molybdenum Sulfides $\mathrm{MoS}_{2}$ for Photoelectrochemical Applications. 9th Annual College of Engineering Research Day, Tampa.

[37] Chemelewski, W.D., Mabayoje, O., Tang, D., Rettie, A.J. and Mullins, C.B. (2016) Bandgap Engineering of $\mathrm{Fe}_{2} \mathrm{O}_{3}$ with Cr-Application to Photoelectrochemical Oxidation. Physical Chemistry Chemical Physics, 18, 1644-1648. https://doi.org/10.1039/C5CP05154A

[38] Sun, S., Sun, M., Kong, Y., Fang, Y. and Yao, Y. (2016) $\mathrm{MoS}_{2}$ and Graphene as Dual, Cocatalysts for Enhanced Visible Light Photocatalytic Activity of $\mathrm{Fe}_{2} \mathrm{O}_{3}$. Journal of Sol-Gel Science and Technology, 80, 719-727.

[39] Srivastava, S. (2012) Synthesis and Characterization of Iron Oxide Nanoparticle from $\mathrm{FeCl}_{3}$ by Using Polyvinyl Alcohol. International Journal of Physical and Social Sciences, 2, 161-184.

[40] Woo, K., Lee, H.J., Ahn, J.-P. and Park, Y.S. (2003) Sol-Gel Mediated Synthesis of $\mathrm{Fe}_{2} \mathrm{O}_{3}$ Nanorods. Advanced Materials, 15, 1761-1764. https://doi.org/10.1002/adma.200305561

[41] Gao, D., Si, M., Li, J., Zhang, J., Zhang, Z., Yang, Z. and Xue, D. (2013) Ferromagnetism in Freestanding $\mathrm{MoS}_{2}$ Nanosheets. Nanoscale Research Letters, 8, 129. https://doi.org/10.1186/1556-276X-8-129

[42] Zhang, Y., Chen, P., Wen, F., Meng, Y., Yuan, B. and Wang, H. (2016) Synthesis of S-Rich Flower-Like $\mathrm{Fe}_{2} \mathrm{O}_{3}-\mathrm{MoS}_{2}$ for $\mathrm{Cr}$ (VI) Removal. Separation Science and Technology, 51, 1779-1786. 
[43] Yang, X., Sun, H., Zhang, L., Zhao, L., Lian, J. and Jiang, Q. (2016) High Efficient Photo-Fenton Catalyst of $\alpha-\mathrm{Fe}_{2} \mathrm{O}_{3} / \mathrm{MoS}_{2}$ Hierarchical Nanoheterostructures: Reutilization for Supercapacitors. Scientific Reports, 6, Article No. 31591. https://doi.org/10.1038/srep31591

[44] Ye, L., Wang, D. and Chen, S. (2016) Fabrication and Enhanced Photoelectrochemical Performance of $\mathrm{MoS}_{2} / \mathrm{S}$-Doped G-C $\mathrm{N}_{3}$ Heterojunction Film. ACS Applied Materials \& Interfaces, 8, 5280-5289. https://doi.org/10.1021/acsami.5b11326

[45] Giambrone, N., McCrory, M., Kumar, A. and Ram, M.K. (2016) Comparative Photoelectrochemical Studies of Ragioregular Polyhexylthiophene with Microdiamond, Nanodiamond and Hexagonal Boron Nitride Hybrid Films. Thin Solid Films, 615, 226-232.

[46] Basnayaka, P.A., Villalba, P., Ram, M.K., Stefanakos, L. and Kumar, A. (2013) Photovoltaic Properties of Multi Walled Carbon Nanotubes-Poly (3-Octathiophene) Conducting Polymer Blends Structures. In: MRS Proceedings, Cambridge University Press, Cambridge, 139-144.

[47] Bard, A.J. and Faulkner, L.R. (1980) Electrochemical Methods. Wiley, New York.

[48] Ram, M.K., Maccioni, E. and Nicolini, C. (1997) The Electrochromic Response of Polyaniline and Its Copolymeric Systems. Thin Solid Films, 303, 27-33.

[49] Ram, M., Sundaresan, N. and Malhotra, B. (1994) Performance of Electrochromic Cells of Polyaniline in Polymeric Electrolytes. Journal of Materials Science Letters, 13, 1490-1493. https://doi.org/10.1007/BF00419144

\section{Submit or recommend next manuscript to SCIRP and we will provide best service for you:}

Accepting pre-submission inquiries through Email, Facebook, LinkedIn, Twitter, etc. A wide selection of journals (inclusive of 9 subjects, more than 200 journals) Providing 24-hour high-quality service User-friendly online submission system Fair and swift peer-review system Efficient typesetting and proofreading procedure Display of the result of downloads and visits, as well as the number of cited articles Maximum dissemination of your research work

Submit your manuscript at: http://papersubmission.scirp.org/

Or contact ajac@scirp.org 